\title{
Society Empowerment through the Business of Fishbone Chips and Meat Shredded Fish Roaster
}

\author{
Ihat Hatimah, Lili Adi Wibowo, Dadang Yunus Lutfiansyah
}

\begin{abstract}
Society empowerment is required as an effort to create an independent society by putting into actual the potential abilities possessed by society. The society empowerment has become one of the most important policy pillars to overcome poverty. It is also considered as an effective way to overcome the problem since the results last long. The approach has always been suitable to solve sources of poverty issues. Likewise, entrepreneurship also plays an important role for society, especially for the development of regional economy through the initiation of small-middle micro business in order to reduce unemployment level in society. Therefore, society empowerment through entrepreneurship program is required to improve life quality, independence, and prosperity. The method used in this study is descriptive analysis, expected to be able to give explanation of empowerment society through the entrepreneurshii program. The findings show that knowledge and skill of society in the Regencies of Indramayu, Cirebon, and Subang are improved after participating in the entrepreneurship program of fishbone chips and shredded fish roaster.
\end{abstract}

Index Terms: Entrepreneurship, Society Empowerment, Independence

\section{INTRODUCTION}

Society empowerment constitutes an effort to improve life standard of left behind society and those under poverty, enabling them to get empowered and independent. Society empowerment is one effort to create/ improve capacity of society, both individual and group, to solve any kinds of problems in relation to the improvements of life quality, independence, and prosperity. According to Kabeer (in Saha, B., \& Sangwan, N., 2019) (1) 'empowerment is the expansion in people's ability to make strategic life choices in a context where this ability was previously denied to them". The ability needs to improve on three inter-related dimensions: resources (access to and claims over material, human and social resources), agency (processes of decision making), and achievements (well-being outcomes).

Revised Manuscript Received on September 22, 2019.

Ihat Hatimah, Department of Community Education, Universitas Pendidikan Indonesia, Bandung, Indonesia. Jl. Dr. Setiabudhi No. 229, Bandung, Indonesia. Email: ihat.hatimah@upi.edu

Dadang Yunus Lutfiansyah, Department of Community Education, Universitas Pendidikan Indonesia, Bandung, Indonesia. J1. Dr. Setiabudhi No. 229, Bandung, Indonesia. Email: dadangyunus@upi.edu

Lili Adi Wibowo, Program of Business Education, Universitas Pendidikan Indonesia, Bandung, Indonesia. Jl. Dr. Setiabudhi No. 229, Bandung, Indonesia. Email: liliadiwibowo@upi.edu.
To put it into actual, the program of society empowerment requires larger involvement from all regional government apparatus and all sides who give opportunities, and who guarantee the continuation of the achievements (Sumodiningrat,1999 in Putra, Pratiwi, \& Suwondo, 2014) (2).

Society empowerment is a social action in which society of a community organizes itself to create collective plan and action to solve social problem or to fulfil social needs in line with skills and sources possessed by the group. Society under poverty are often unempowered due to both internal restriction, from itself, and external pressure, from its neighborhood. Therefore, empowerment society becomes one

of the most important policy pillars to overcome poverty. This society empowerment is considered as an effective way since it lasts long. The approach has always been suitable to solve sources of poverty issues.

Society empowerment is highly required to make the societies independent through the realization of potential ability possessed by them. To increase the society empowerment in economy sector, the government has a program, known as UMKM, or Usaha Mikro Kecil dan Menengah, or Middle and Small Micro Business. Despite the inexistence of standard definition of this term in Indonesian dictionary and encyclopedy, UMKM is often practically related to a limited investment by an individual or group to run a business. Generally, this type of business is highly associated with the category of middle to low society. Even so, this type of business cannot be underestimated. This business existence has opened societies' eyes, particularly those who are involved within the business world. Therefore, it is no longer a question to find the fact that many businessmen initiate their business with this type and develops into a successful business.

Entrepreneurship has also an important role for society, particularly for regional economy development, through the initiation of small-middle micro business in order to reduce unemployment level in society. Unemployment has actually been one issue for developing country. To reduce the problem and further to improve prosperity of society, one effort is by giving society entrepreneurship education at the earliest stage possible. According to United Nation and World Bank (in Bhuiyan, M.F., \& Ivlevs, A, 2018) (3) entrepreneurship has been long hailed as an important tool to reduce poverty and promote economic growth in developing countries.

Development by the government has kept on going with the aims to improve the life standard of society. The

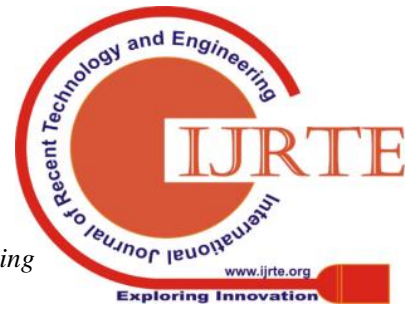


development by the government is, in the form of, not only infrastructure but also economy. Development of society economy aims to provide prosperity for all socities, particularly for those middle to low class. One of the efforts to build this economy is by inviting society to create independent business, giving the people less chance to depend their lives on income as company laborers or staffs. This government effort has generated a wider business competition in society and thus necesitates to possess specialized skills to initiate new business and gain income. In the current "remedial" view, entrepreneurship viewed as a means for addressing financial insecurity and improving the lives of individual entrepreneurs (sutter et al, 2019). (4)

One of the directions in the national competition power development in RPJPN 2005-2025 is the development of qualified human resources. Therefore, education is required to build society. Societies expect that education can bring them to get advanced in all fields, put them at ease at getting job and result in prosperity. Likewise, the government expect that society can be empowered can play an active role in the development of nation. Education in the program of society empowerement essentially educates the societies to figure out the strenghths and weaknesses they have, to direct them to overcome problem, to create activity programs, and to implement the results to achieve prosperity.

Djohani in Kusnandi, (2005:220), (5) states that society empowerment is aimed to develop the ability of societies to be independent in solving their own problems. It is to create or improve their capacity, both individual and in group to solve any kinds of problems in relation to the efforts to improve their life quality, independence, and prosperity.

Society empowerment is instrumental and mandatory, aligned with the fast developments of economy and technology lately that highly influences people's ability to fulfil their needs.(A. Mustanir \& Lubis, 2017) (6). Therefore, societies in general are expected to be able to go along with the era development through the program of society empowerment, with the aims as follows.

1) to create independent individuals within society;

2) to create good work ethic environment, to create healthy and mutual working condition;

3 ) to create society with good and high awareness of self and surroundings potentials;

4) to train and enable societies to arrange plan and responsibilities on their own actions to fulfil their needs;

5) to enhance their thinking ability towards problems in their surroundings; and

6) to minimize poverty rate through the improvement of potential and basic ability possessed by society.

Sunartiningsih, (2009:140) (7) explains that the process of society empowerment is expected to enable the societies to:

1) analyze situation in their surroundings;

2) look for solution for problems based on their ability and limitations;

3) improve members' life qualities;

4) improve income and life standard; and

5) develop system to access required sources.

Basically, entrepreneurship is a nature, feature, and character of an individual who has a strong will to creatively put into actual innovative ideas. In an extreme term, an entrepreneur is defined as one who can turn garbages into gold. The word entrepreneur was introduced by Joseph Schumpeter, an Austrian economist in 1883-1950. Schumpeter thought that the process of economy change is basically influenced by the attitude of each individual, in this case, is the entrepreneur as the business actor. Therefore, entrepreneurship always looks for new things as one challenge to change and the change is used as an opportunity (Mustanir, 2019:5) (8).

\section{LITERATURE REVIEW}

The first concept is about the term pemberdayaan is a translation of empowerment which is the result of thinking and study of the human mind and western culture (Europe) which began to appear around the 1970s and was disputed and developed continuously in the 80 s, and the 90 s to the end 20th century. Empowerment emerged as an important theme especially in the participatory, emancipatory, democratization movements including the women's movement and other oppressed movements in organizing society and the growth of new-populism and in progressive movements for peace and social justice (Kresberg in Ife, 1998) [9].

Next, the second conception in this article is about entrepreneurship, in his book Entrepreneurship, Robert Hisrich and Michael Peters (1995), as quoted by Buchari Alma (2000), said the process of creating something different with value by devoting the necessary time and effort, assuming the accompanying financial, psychological, and social risks and receiving the resulting rewards of monetary and personal satisfaction.[10]. entrepreneurship can be viewed from three main elements, namely: motivation, organization and society (Durieux and Stebbins, 2010) [11].

\section{METHOD}

The method used in the study was descriptive analysis, functioning to describe or give an illustration on object under investigation through data or samples collected as they were without doing the analysis and drawing conclusion applied for general purpose (Sugiyono, 2008:29) (12). In other words, descriptive analysis research focuses on an issue or centers its attention to problems as they are when the research is conducted, the results are later managed and analyzed to achieve conclusion. Descriptive analysis is expected to give explanation regarding society empowerment through entrepreneurship, illustrating characteristics of the society.

\section{RESULT AND DISCUSSION}

\section{A. A Preview Before Knowing Entrepreneurship}

Results of descriptive analysis showed that respondents had high curiousity regarding entrepreneurship prior to program introduction. It indicates that respondents need it as their priority to improve their knowledge, character, and skills, particularly with respect to entrepreneurship. The needs analysis activity was conducted together with

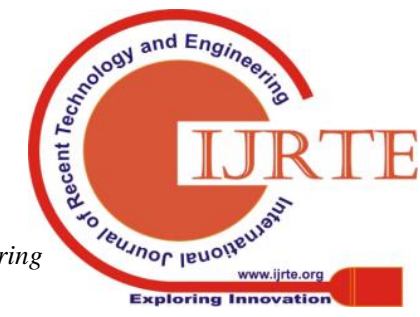


the implementer, advisor, and several society figures so that the materials delivered were in line with the expectations and interests of learners.

The results also give an illustration that before knowing entrepreneurship, the needs to curiosity regarding the program and the needs to learn entrepreneurship are the main factors to define, and thus in the initial stage, learning needs identification is necessary to carry out. This result is in consistent with the concept of planning experts in Nonformal Education, one of them is the concept suggested by Sudjana (2010) (13) stating that planning of Nonformal education program (adults education) is highly suggested to initiate with learning needs identification of learners involving elements of implementer, learning sources, and learners.

Further, the results of the research with respect to motivation of learners participating in the entrepreneurship showed that respondents had high motivation to initiate business, in this case, the motivation is defined as a compulsion to gain knowledge and to practice the knowledge obtained to enable oneself to be empowered and independent, to increase income to fulfil family needs and to help earn money for family. One's motivation to learn, namely: (a) intrinsic motivation, which is within individual such as from needs, talents, wants, interests, and hopes, (b) extrinsic motivation comes from the outside of individual, emerged because of stimulus from the external factor.

The results of the reseach describe that knowledge and skills possessed by respondents to initiate business after the training can be considered enough, despite little business experience and limited investment. Those factors are no longer restrictions for the respondents to encourage themselves to initiate business. This mental attitude has become the trigger for learners to start a business. Therefore, to have a business refers to mental attitude, power, and thought to acieve one aim.

\section{B. Preview on the Process of Knowing Entrepreneurship}

The implementation of program to get to know entrepreneurship constitutes a transformation processes of knowledge, skills, and attitudes of learning sources, or in this case is tutor to learners. The implementation of entrepreneurship program through the management skill of local potential culinary is not separated from the setting curriculum by the existence of program aims, that is, to give knowledge and abilities with respect to skills to manage any kinds of foods and to have an entrepreneur attitude supporting for the business development of learners or respondents.

The results of the research showed that the process to get to know entrepreneurship is an educative interaction between learners and other components, namely raw input comprising learners, inputs of facilities involving budget sources, aims of the program, curriculum, educators, program managements, learning sources, media, facilities, funds, and program management, environmental input, namely; family and social environments, climate, location, living places, and other inputs, including budget or investment, job field/business, tools and facilities, and marketing. The results, in general, have actually supported and strengthened conceptual signs regarding the components of nonformal education as outlined by Sudjana (2010 : 35-35)
(14) stating that ongoing learning process involves the following components:

1) Instrumental input comprising all sources and facilities enabling an individual or group to conduct learning activity.

2) Raw input including learners with their own characteristics.

3) Environmental input, involving environmental factors that support or encourage the running of education program

4) Process that involves interaction among facilities, maily tutors with the raw input and those are learners.

5) Output that is the quantity of qualified graduates with the change of behavior obtained through learning activity that make the students learn.

6) Other inputs include other supportive factors enabling the leaners and graduates to use their ability to advance their lives

7) Impact in relation to the results that have been achieved by the learners and graduates.

Program to get to know entrepreneurship carried out by the implementer is to awaken and improve learning as a part of the learning activity itself in order to create learners who have knowledge, abilities, and skills of entrepreneurship that support the business development of learners, and is eventually expected to give impact on the improvement of job opportunities and family income.

The results of the research also illustrate that the materials delivered in the entrepreneurship learning show positive trends, respondents thought that the materials were interesting, indicating that the content of the materials delivered constitute something new for learners and were in line with the needs of the learner. This is in line with the statements of the implementer and sources persons stating that the materials were arranged and formulated to fufil the needs and interest of the learners. In this process, the materials were arranged in the form of hand outs and were delivered based on the setting topics. Apart from that, the performance of the tutor in delivering the materials (the method of material delivery) has become one of the keys to stimulate learners or participants stated that the materials were interesting.

The results of interview with the resource person/ facilitator/tutor in each meeting of entrepreneurship learning showed that learning media were varying from their types and levels. Facilities in terms of of types and facilities that can support the implementation of learning activity based on the setting aims. Learning facilities can function as: (a) facilities of learning instruments, and (b) learning sources (Abdulhak, 2000). (15)

Further, with respect to the learning source or tutor who delivers the materials of entrepreneurship, respondents also gave positive responses, implying that the tutors played a good role in doing their jobs in delivering the materials and in facilitating learners to better understand the materials focused on. This is in line with Irmawita (2015) (16) illustrating that tutors as the educators conducting the teaching, guidance, and training to learners or trainees must arrange learning program, using strategy, media, method, and learning 
approach suitable for adults learning characteristics.

This is also in line with Knowles (1979) (17) who defines andragogy the science and arts of helping adults learn. This suitability takes into account adnragogy learning principles, learning needs, and local potential. To measure this successful learning factor, tutor must prepare standard and measurable instruments to determine an accurate and reliable learning results. This is known as facilitation role or function. In general, facilitation is defined as a process to simplify something in order to achieve particular aim. In this case, those who simplify it are called facilitator.

The results illustrate that andragogy learning is a society learning phenomenon that happens and can be applies in many kinds or forms of unit and program of nonformal education. Further, viewed from the characteristics of learners, andragogy learning is suitable for a group of society with low level of education and social economy. Another result in relation to the application of andragogy is that the characteristics of andragogy learning is understood and can be used as a referrence for the implementer if literacy education through entrepreneurship, especially by the involvement of learners to explore their experience.

The results also showed that good media for learning and practice as well as other means (for learning and practice) must be based on one account that the learning is to give compulsion, to grow learning interest, to create conducive learning climate, to give fin and to strengthen the materials learnt, to enhance energy to bear creativity, to motivate to have self evaluation in the process and result of learning, and to compel learners to complete the weakness of learning result deriving from the learners themselves (Abdulhak, 2000).

\section{Preview After Knowing Entrepreneurship}

The result of the research demonstrated that most respondents showed high confidence to initiate business after they had participated in the program of entrepreneurship. It means that entrepreneurship learning has improved the learners' confidence, initially having a hesitation to start a business and then having a courage to open a business and having faith in doing it. This is one solution to improve family income. Entrepreneurship education, has offered its customers (i.e., women) very mixed experience (Walter, Parboteeah, \& Walter, 2013) (18).Specifically, while some prior studies reveal that entrepreneurship education fosters entrepreneurial attitude, intention or behavior through enhanced entrepreneurial interest and competency (e.g., Bae, Qian, Miao, \& Fiet, 2014; Kuratko, 2005; Martin, McNally, \& Kay, 2013) (19).

Further, the data of the research also showed that respondents had a strong will to practice the result of training on entrepreneurship, meaning that spirit and courage to deliver back the learning materials to someone else become the indicator of success from the program of post basic literacy-based entrepreneuership and the indicator that motivation to implement the knowledge gained by the learners is high.

Attitude of creativity of learners is also high, shown by the emergence of ideas and new thoughts in choosing types of business to be carried out in line with the skill and local potential. Further, in relation to the advantages gained after the training of entrepreneurship, the results are marked as low. It is actually an interesting phenomenon to assume the respondents' understanding regarding the value of advantage itself, what does it constitute? Does it refer to the material only, or to other aspects such as the increase of knowledge and skills? It is relevant because the later aspects can also be considered as advantages gained by the learners.

The data also illustrated the changes of attitude after the participation in the program of entrepreneurship as can be seen in Table 4.9 below.

Tabel 4.9

The Changes of Attitude of Entrepreneurship after Leaners Participated in the Program of Entrepreneurship

\begin{tabular}{|c|c|c|}
\hline No & $\begin{array}{c}\text { Attitude of } \\
\text { Entrepreneurshi } \\
\mathrm{p}\end{array}$ & $\begin{array}{l}\text { After Knowing } \\
\text { Entrepreneurship }\end{array}$ \\
\hline 1 & $\begin{array}{l}\text { Confident; } \\
\text { independent, } \\
\text { optimistic }\end{array}$ & $\begin{array}{l}\text { To have courage to open a } \\
\text { business in culinary (Food } \\
\text { management such as fishbone } \\
\text { chips and shredded fish roaster) } \\
\text { To have confidence to start and } \\
\text { run a business } \\
\text { To have a courage to start a } \\
\text { business }\end{array}$ \\
\hline 2 & $\begin{array}{l}\text { A will to practice } \\
\text { the result of } \\
\text { training: The } \\
\text { needs to be } \\
\text { persistent, to } \\
\text { work hadr, to } \\
\text { have a strong } \\
\text { will, and to have } \\
\text { initiative }\end{array}$ & $\begin{array}{l}\text { Working hard, being persistent } \\
\text { (Attendance is } 75 \% \text { ) } \\
\text { Developing skills in culinary } \\
\text { business (Fishbone chips and } \\
\text { shredded fish roaster) } \\
\text { Feeling dissatisfied with the } \\
\text { result of the business they have } \\
\text { done } \\
\text { Delivering back the materials/ } \\
\text { skills that have been obtained to } \\
\text { someone else. }\end{array}$ \\
\hline 3 & $\begin{array}{l}\text { Originalities: the } \\
\text { emergence of } \\
\text { ideas and new } \\
\text { thoughts } \\
\text { (innovative and } \\
\text { creative) }\end{array}$ & $\begin{array}{l}\text { Being active in looking for and } \\
\text { attempting the development of } \\
\text { market } \\
\text { Being able to make use of } \\
\text { opportunity }\end{array}$ \\
\hline 4 & $\begin{array}{l}\text { Advantage } \\
\text { gained after } \\
\text { participating in } \\
\text { the training }\end{array}$ & $\begin{array}{l}\text { Enhancing knowledge and skills } \\
\text { Working more dilligent to gain } \\
\text { more income } \\
\text { Having more spirit to advance } \\
\text { and work in culinary business } \\
\text { (fishbone chip and shredded fish } \\
\text { roaster) }\end{array}$ \\
\hline 5 & $\begin{array}{l}\text { A will to keep } \\
\text { participating in } \\
\text { the training }\end{array}$ & $\begin{array}{l}\text { Being easy to adjust oneself with } \\
\text { working environment } \\
\text { Being easy to mingle with others }\end{array}$ \\
\hline
\end{tabular}

(Source: Document of Implementer, 2019)

The research found that substantially learners had good understanding and had applied the true values of entrepreneurship, relevant with Suryana (2006:15) (20) stating that there are some true and important values of entrepreneurship, namely:

1) Self confidence, it influences on the ideas, intentions, initiatives, creativities, courages, hard working spirits, and passion to create something. 
2) Task and result oriented, someone who always puts priorities on task and result is one who always prioritizes prestiges values, profit oriented, persistent and resilient, determined to work hard, have a strong compulsion, energic, and to have initiative.

3) Dare to take risk, it depends on the attraction of each alternative, the preparation when facing disadvantages, and relative possibility to being succeed or failed. The ability to take risk determined by self faith, willingness to use the ability, and the ability to evaluate risks.

4) Entrepreneurship leadership has a leading anc role model character, outstanding, and has divergent and convergent thoughts.

5) Originalities: Creativities and innovation. Creativity is an ability to think new and different, while innovation means an ability to act new and different.

Data from the research also showed that the willing to keep participating in the entrepreneurship program is low. It means that the implementer needs to evaluate factors causing the problem, whether human resources (tutor/instructor), or other supporting sources when the post basic literacy entrepreneurship program is conducted, and thus evaluation and monitoring after the entrepreneurship program are required to carry out.

The data also showed that monitoring and fostering of entrepreneurship program in the field is the follow-up after the program is finished to conduct. The monitoring activity has four main aims, as follows: (a) to find out how far the groups are able to apply the knowledge, attitude, and skill that they have possessed resulted from the training/ learning in the actual business activity in the field, (b) to find out the development of business activity of the learning groups from time to time and the problems they face when they run business, (c) to collect data and information regarding success or failure and factors contributing to either of them as an input to the implementer/manager/tutor to do the follow-up, and (d) to document information and other findings in the field during the implementation of business activity.

This is also aligned with Sudjana (2010 : 253) (21) stating that monitoring in general is carried out before the fostering program or at the same time with the implementation of the program. In the earlier section, it is also discussed the follow-up program after the training, that is by carrying out the accompaniment program. Accompanyment in the KBBI or Kamus Besar Bahasa Indonesia (literally: Big Dictionary of Indonesian Language) refers to a process in accompanying closely like a best friend and a relative living together in good and bad, helping each other to face the life to achieve the setting purpose.

\section{Preview On the Result of Pre and Post Tests of Entrepreneurship}

The result of pre and post tests of entrepreneurship skill through the program of entrepreneurship showed different score. Before the program was introduced, the average score of learners was 60.60 and after the program was carried out, the average score was 64.13 . The gap between the pre and post tests is 3.53 or $4.71 \%$, the highest gap score is 8 or $10.7 \%$, while the lowest gap score is 1 , showing that there is an increase with respect to reading, writing, and arithmethic skills of learners after participating in the program. The result of pretest showed that the initial skill of learners' entrepreneurship is still low, however after the treatment was conducted, there was an increase by 3.53 or $4.71 \%$. The change of the score can be seen in the following figure.

Figure 4.10

The Result of Pre and Post Test of Entrepreneurship Ability

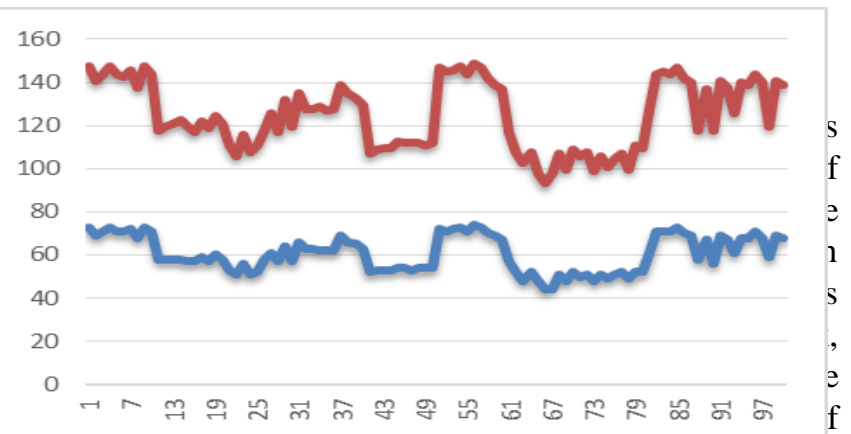

oneself, family, and society. This program is designed to guide, facilitate, train, and make the learners learnt, enabling them to have a better future.

The research demonstrated that learners had better knowledge, skill, and attitude after the program was carried out. To maintain clarity, each aspect will be explained separately.

\section{1) Knoweldge Aspect}

After participating in the entrepreneurship program, learners had better understanding on the materials they learnt, including vocational skill, particularly in culinary, and simple accounting. This success is attributed to high motivation, curiosity, attendance, and hard work of leaners to participate in the training and from the support given by the local government apparatus to motivate learners to participate in the entrepreneurship program.

The improvement in knowledge of earners is highly influenced by the tutor or the resource person in delivering the materials. Interesting materials, varying techniques in delivering them, and using methods and techniques making the learners better understand the materials and easy to apply, such as dialogic-andragogy approach have given a conducive and fun learning. It creates closeness between the tutors and learners, enabling them to be much easier in materials delivery.

\section{2) Attitude and Skill Aspects}

After participating in the program, learners had better attitude, particularly with respect to self confidence. It could be seen from some interactions in the class, for instance, they were confident to share opinion within the group or in public, to have an initiative to start business/ activity, to be more open to other's opinion within group, and to motivate one another in the group. Likewise, learners were better as they had strong will to learn, to start business, to make use of the knowledge they learnt, and to apply the knowledge, skill and attitude they learnt in entrepreneurship program into their own business, which is culinary. This result of the study are related to Muellers (2011, p. 69) (22) that entrepreneurship education influences changes in attitudes, perceptions, and intentions of the community in entrepreneurship

The description illustrates that learners generally are

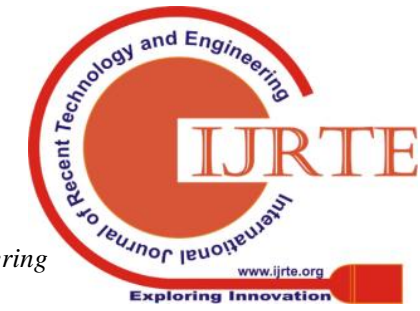


highly motivated, diligent, hard working, passionate, and enthusiastic. They also have developed values they have learnt from entrepreneurship training and they can make use of those. The changes in attitude and behavior felt by the respondents are influenced by knowledge and skill they possessed from the training. Krec in Ahmadi (2007:159) (23) states that:

Individual attitude is formed by information one receives. The change in one's attitude with respect to relation with many kinds of objects in or out of him will cause the attitude to be stronger or conversely. It depends on individual experience in relation to his attitude.

This opinion strengthens the result of the research, illustrating that attitude and behavior of learners are highly influenced by their life experience, including the result of training they obtained. If learners have new experience, then they will have new cognition regarding things they learnt, knowledge and skill as the result of training will influence on their attitude and behavior in things they do.

The change in attitude and behavior of entrepreneurship is highly influenced by many factors, both internal and external. Internal factors cover psychological condition, needs, will and want, and expectation coming from within individual, while external factors cover social environment, interpersonal relation, experience and result of learning, all comes from the outside of the individual. Internal factors constitutes power motivating one individual to act or do somehing to achieve the setting goals and thus this internal factor will turn into a motive. Meanwhile, external factor refers to instruments, or means to do something in order to achieve the setting aims. In the entrepreneurship program, external factors, in fact, highly influence learners' mental, as once there was a misscommunication among learners causing a dispute between learners/ groups, for example: transparancy in profit obtained, investment, high dependence on the local facilitator so that the ability of leadership of the group was not working.

\section{CONCLUSION}

Entrepreneurship program conducted in Regencies of Indramayu, Cirebon, and Subang gives a significant result because learners after participating in the program shows improvement with respect to knowledge, attitude, and skills. In terms of knowledge aspect, learners have a better understanding on the entrepreneurship matreials, vocational skills, simple accounting, and marketing. In the aspect of attitude, learners have high confidence, courage to start a business, openess to other's opinion, encouragement for others, strong will to learn and to try to get knowledge, and to apply the knowledge into their own business in culinary. With respect to skill, learners are more skilled in making fishbone chips and shredded fish roaster.

\section{Acknowledgement}

We would like to express our deepest gratitude to Department of Community Education for the research opportunity. We would like to also appreciate PP-PAUD DIKMAS Jaya Giri as the partner who has helped the research from the beginning till its completion.

\section{REFERENCES}

1. Saha, B., \& Sangwan, N. Credit where credit's due: The enabling effects of empowerment in Indian microfinance. World Development. 2019. 122, 537-551.doi:10.1016/j.worlddev.2019.06.009

2. Putra, C. K., Pratiwi, R. N., \& Suwondo. Pengelolaan Alokasi Dana Desa dalam Pemberdayaan Masyarakat Desa,. Jurnal Administrasi Publik, 2. 2014.

3. Bhuiyan, M. F., \& Ivlevs, A. Micro-entrepreneurship and subjective well-being: Evidence from rural Bangladesh. Journal of Business Venturing. 2018. doi:10.1016/j.jbusvent.2018.09.005

4. Sutter, C., Bruton, G.D., Chen, J. Entrepreneurship as a solution to extreme poverty_a review and future research directions. J. Bus. Ventur. 2019. 34 (1), 197-214.

5. Kusnandi. Pendidikan Keaksaraan; Filosofi, Strategi dan Implementasi Jakarta: Departemen Pendidikan Nasional. 2005.

6. Mustanir, A., \& Lubis, S. Participatory Rural Appraisal in Deliberations of Development Planning. In International Conference On Democracy, Accountability, and Governance. 2017. 163, 299.

7. Sunartiningsih, A. Pemberdayaan Masyarakat Desa melalui Institusi Lokal. Yogyakarta: Aditya Media. 2009.

8. Mustanir, A. Pemberdayaan Masyarakat Kewirausahaan Entrepreneurship Community Empowerment. 2019.

9. Ife, J. Community Development. New York: Macmillan Publishing Company. (1998).

10. Alma, B. Kewirausahaan. Bandung : Alfa Beta. 2005.

11. Durieux, M.B \& Stebbins, R.A.. Social Entrepreneurship for Dummies.Indianapolis: Wiley Publishing, Inc. 2010

12. Sugiyono. Metode Penelitian Kuantitatif Kualitatif dan R\&D. Bandung: Alfabeta. 2008

13. Sudjana. Manajemen Program Pendidikan. Bandung: Untuk pendidikan luar sekolah dan Pengembangan Sumber Daya Manusia.: Falah Production. 2010.

14. Sudjana. Pendidikan Luar Sekolah: Wawasan, Sejarah Perkembangan, falsafah, teori pendukung, azas. Bandung: Falah Production. 2010.

15. Abdulhak. Metodologi Pembelajaran Orang Dewasa. Bandung: Andira. 2000 .

16. Irmawita. Buku Panduan Untuk Tutor Model Pengelolaan Program Pendidikan Keaksaraan Fungsional Berbasis Kebutuhan Belajar Masyarakat. Padang: Universitas Negeri Padang. 2015.

17. Knowles, Malcolm The Adult Learning (thirt Edition), Houston, Paris, London, Tokyo: Gulf Publishing Company. 1979.

18. Walter, S. G., Parboteeah, K. P., \& Walter, A. University departments and selfemployment intentions of business students: A cross-level analysis. Entrepreneurship Theory and Practice. 2013. 37(2), 175-200

19. Bae, T. J., Qian, S., Miao, C., \& Fiet, J. O. The relationship between entrepreneurship education and entrepreneurial intentions: A meta-analytic review. Entrepreneurship Theory and Practice. 2014 38(2), 217-254

20. Suryana. Kewirausahaan Pedoman Praktis ; Kiat dan Proses Menuju Sukses, Edisi Ketiga, Jakarta : Penerbit Salemba. 2006.

21. Sudjana. Manajemen Program Pendidikan. Bandung: Untuk pendidikan luar sekolah dan Pengembangan Sumber Daya Manusia.: Falah Production. 2010.

22. Mueller, S. Increasing entrepreneurial intention: effective entrepreneurship course characteristics. International Journal of Entrepreneurship and Small Business. 2011. 13(1), 55.doi:10.1504/ijesb.2011.040416

23. Ahmadi, Abu. Psikologi Sosial. Jakarta; Rineka Cipta. 2007

\section{AUTHORS PROFILE}

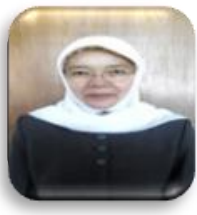

Ihat Hatimah, Professor at Community Education Department, Universitas Pendidikan Indonesia Reasearcher in Literacy, parenting and community empowerment. 
Lili Adi Wibowo, Lecture at Program of Business Education, Universitas Pendidikan Indonesia. Reasearcher in Economic and business.

Dadang Yunus Lutfiansyah, Lecture at Community Education Department, Universitas Pendidikan Indonesia. Researcher in Empowering, Andragogy, Trainning and Community Education. 